\title{
HADIS SEBAGAI SUMBER HUKUM ISLAM (Telaah Terhadap Penetapan Kesahihan Hadis Sebagai Sumber Hukum Menurut Syafi'iy)
}

\author{
Nasruddin Yusuf \\ Institut Agama Islam Negeri Manado, Manado, Indonesia \\ nasruddin.yusuf@iain-manado.ac.id
}

\begin{abstract}
Hadiths are not sacred texts as the Koran. However, the hadith is always the second reference after the Koran and occupies an important position in Islamic studies. Considering the writing of the hadith which was carried out hundreds of years after the Prophet Muhammad died, many opinions were crossed over the validity of a hadith. so that this raises some groups to doubt and deny the truth of the hadith as a source of law. This paper will focus on discussing the study of the determination of the validity of hadith as a source of law according to Imam Syafii. This paper uses the library research method with the study of text analysis, therefore the author refers directly to the books written by Imam Shafi'i and makes comparisons with books written by the Muhadits. The findings in this research that about the debate about the hadith tradition as a source of law in Islam, al-Syäfi'iy seems to hold on the opinion that the provisions contained in the hadith are in the laws of the Qur'an; With katalam, the hadith of Nabi can only add to the law in the Qur'an. He said that the existing form of command, both the Qur'an and the hadith, is based on the same source, even though it is through a different path.
\end{abstract}

Keywords:Hadith, Al-Quran, Imam Shafi'i, Muhadits, Islamic Law.

Abstrak.Hadits bukanlah teks suci sebagaimana Al-Quran.Namun, hadits selalu menjadi rujukan kedua setelah Al-Quran dan menempati posisi penting dalam kajian keislaman.Mengingat penulisan hadits yang dilakukan ratusan tahun setelah nabi Muhammad SAW wafat, maka banyak terjadi silang pendapat terhadap keabsahan sebuah hadits.sehingga hal tersebut memunculkan sebagian kelompok meragukan dan mengingkari akan kebenaran hadits sebagai sumber hukum. Tulisan ini akan fokus membahas tentang telaah terhadap penetapan kesahihan hadits sebagai sumber hukum menurut Imam Syafii. Tulisan ini menggunakan metode library research dengan studi analisa teks, karena itu penulis merujuk langsung kitab-kitab yang ditulis oleh Imam Syafi'I dan melakukan perbandingan dengan kitab yang ditulis oleh para muhadits.Temuan dalam riset ini bahwa 
tentang perdebatan soal keshahihan hadits sebagai sumber hukum dalam Islam, alSyäfi'iy nampak beıpegang pada pendapat bahwa ketentuan-ketentuan yang ada dalam hadis berada dalam hukum-hukum Alquran; Dengan katalam, hadis Nabı dapat saja menambah hukum yang ada dalam Alquran.Ia mengatakan bahwa wujud perintah yang ada, baik dan alquran maupun hadis, adalah berpangkal dari sumber yang sama, meskipun melalui jalur yang berbeda.

Kata Kunci:Hadits, Al-Quran, Imam Syafi i, Muhadits, Hukum Islam.

\section{Pendahuluan}

Al-Hadits didefinisikan pada umunya oleh ulama seperti definisi AlSunnah yaitu sebagai segala sesuatu yang dinisbatkan kepada Muhammad SAW, baik ucapan, perbuatan maupun taqrir (ketetapan), Sifat fisik dan psikis, baik sebelum beliau menjadi nabi atau sudah menjadi nabi. Ulama ushul fiqih membatasi pengertian hadits hanya pada ucapan-ucapan Nabi Muhammad SAW yang berkaitan dengan hukum"; sedangkan bila mencakup perbuatan dan taqrir beliau yang berkaitan dengan hukum, maka ketiga hal ini mereka namai dengan sunnah. Pengertian hadits seperti yang dikemukakan oleh ulama ushul fiqih tersebut, dapat dikatakan sebagai bagian dari wahyu Allah SWT yang tidak berbeda dari segi kewajiban menaatinya dan ketetapan-ketetapan hukum yang bersumber dari wahyu AlQuran. $^{1}$

Imam Syafi i sebagai ulama fiqih dalam karya-karyanya banyak menulis tentang ilmu hadits, misalnya dalam kitab al risalah dan al-umm yang menarik untuk dikaji secara mendalam, salah satunya yakni tentang hadits mukhtalif yang banyak diperdebatkan oleh para muhadits. Tulisan ini akan mengurai soal penetapan keshahihan hadits sebagai sumber hukum dalam Islam menurut Imam Syafi i.

\section{Pembahasan}

\section{Fungsi dan Kedudukan Hadis}

Sekiranya hadis Nabi hanya berkedudukan sebagai sumber sejarah, niscaya perhatian ulama terhadap penelitian kesahihan hadis akan lain daripada yang ada sekarang ini.

\footnotetext{
${ }^{1}$ Quraisy Shihab, Membumikan AlQuran, (Bandung: Mizan, 1994), hlm. 21.
} 
Kedudukan hadis, menurut kesepakatan mayoritas ulama, adalah sebagai salah satu sumber ajaran Islam. ${ }^{2} A k a n$ tetapi, terdapat juga sekelompok kecil dan kalangan "ulama" dan umat Islam telah menolak hadis sebagai salah satu sumber ajaran Islam.Mereka ini biasa dikenal sebutan inkar al-Sunnah.

Pada zaman Nabi (w. 632 M.), belum atau tidak ada bukti sejarah yang menjelaskan bahwa telah ada dari kalangan umat Islam yang menolak hadis sebagai salah satu sumber ajaran Islam.Bahkan pada masaal-Khulafa' alRasyidin (632 M.-661 M.) dan Bani Umayyah (661M.750M.), belum terlihat jelas adanya kalangan umat Islam yang menolak hadis sebagai salah satu sumber ajaran Islam. Mereka yang berpaham inkar

$$
\text { al- }
$$

Sunnah, sebagaimana yang diidentifikasikan oleh Syuhudi Ismail, barulah munculpada awal masa 'Abbasyiah (750 M.-1258 M.). ${ }^{3}$ Mereka juga dikenal dengan sebutan munkir alSunnah.

${ }^{2}$ Ali Sâyis, Nasy'at al-Fiqh al-ĩjtihådiy wa Atwaruhu (t.t.: Silsilat aJ-Buhus al-lslâmiy, 1970 M.), h. 57.

${ }^{3} \mathrm{M}$ Syuhudi Ismail, Hadits Nabi Menurut Pembela Pengingkar, dan Pemalsunya (Cet I; Jakarta: Gema Insani Press, 1995 M.), h. 14.
Adanya kelompok yang menolak hadis itu diketahui melalui tulisantulisan al-Syafi'iy. Mereka itu oleh alSyafi'iy dibagi tiga golongan, yakni: (1) golongan yang menolak seluruh sunnah;4 (2) golongan yang menolak sannah, kecuali 'bila sunnah itu memiliki kesamaan dengan petunjuk Alquran; (3) golongan yang menolak sunnah yang berstatus ahad 5 Dua golongan yang disebutkan pertama sekali, sebagaimana dijelaskan Ahmad Yusuf, sebenarnya dapat dikelompokkan menjadi satu, karena kedua-duanya sama-sama menolak kewajiban-kewajiban yang timbul dari hadis. ${ }^{6}$

$$
\text { Cukup banyak dalil yang }
$$
dikemukakan oleh pengingkar hadis ini, baik berupa ayat Alquran maupun interpretasi terhadap ayat itu sendiri. Di antara ayat Alquran yang mereka

${ }^{4}$ Terdapat perbedaan tentang siapa yang dimaksud al-Syafi'iy dengan golongan pertama tersebut.Hal itu disebabkan tidak adanya penjelasan dari al-Syafi'iy sendiri.Uraian dari Abu Zahrah menjelaskan bahwa Khudariy Berberpendapat golongan yang dimaksud al-Syfifi'iy itu adalah orangorang dari golongan Mu'tazilah.Akan tetapi, menurut Abu Zahrah sendiri, mereka adalah orang-orang Zindiq dan sebagian dari Khawarij. Penjelasan selanjutnya, lihat Abu Zahrah, alSyafi 'iy (Cet I; Kairo: Dar al-Fikr al-'Arabiy, t.th), h. 192.

${ }^{5}$ Muhammad ibn Idris al-Syãfi'iy, alUmm, Juz VII (t.t.: Dâr al-Sya'b, t th) h. 250-265.

${ }^{6}$ Ahmad Yusuf, al-Syafi'iy Wadi' 'llm alUsuI (Kairo: Dar al-Saqafah, t.th.), h 73. 
sebutkan, sebagaimana ditulis al- dengan Alquran sebagai sumber ajaran Syafi'iy, adalah Alquran S. al-Nahl: 89 Islam.

berbunyi:

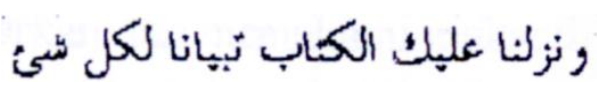

Artinya:

Dan kami turunkan kepadamu Alkitab (AIquran) untuk menjelaskansegala sesuatu

Menurut mereka, ayat dialas dan semakna dengannya menunjukkan secara jelas bahwa Alquran telah mencakup segala sesuatu berkenaan dengan ketentuan agama.Oleh karena itu, tidak diperlukan keterangan lainnya, misalnya hadis.Selain itu, mereka menyatakan bahwa Alquran diturunkan dalam bahasa Arab. Mereka yang memiliki pengetahuan yang mendalam tentang bahasa Arab akan mampu memahami Alquran dengan baik tanpa bantuan hadis. Hal itu, menurut mereka juga, belum lagi ditambahi dengan keadaan seseorang yang tidak mungkin secara akal terbebas dari kesalahan dan kelupaan.7Jadi dalam hal ini, sangat sulit untuk mensejajarkan posisi hadis

\footnotetext{
${ }^{7}$ Al-Syafi'iy, al-Umm., h. 250; Muhammad Abu Zahw, al-Hadis wa almuhadisun (Mesir Matba'at Misr, t.th), h. 21.
}

Argumen-argumen yang mereka sebutkan, menurut al-Syafi'iy tidak kuat. Menurutnya, mereka salah dalam menafsirkan dan memahami maksud kata tibyan (penjelasan) yang termuat dalam Surat al-Nahl:89 Al-Syafi'iy menilai kata itu mempunyai beberapa cakupan pengertian, yakni (1) Ayat Alquran secara tegas menjelaskan adanya, berbagai kewajiban, misalnya kewajiban shalat, puasa, zakat, dan haji; berbagai larangan, misalnya laranganlarangan berbuat zina, meminum minuman keras, memakan bangkai, darah, dan daging Babi dan berbagai teknis pelaksanaan ibadah tertentu, misalnya tata-cara berwudu; (2) Ayat Alquran dalam penjelasannya tentang kewajiban tertentu masih bersifat global, misalnya kewajiban sholat;dalam hal ini, hadis Nabi menjelaskan teknis pelaksanaannya; (3) Nabi menetapkan suatu ketentuan yang dalam Alquran ketentuan itu tidak dikemukakan secara tegas. Ketentuan dalam hadis tersebut wajib ditaati, sebab Allah memerintahkan kepada orang-orang yang beriman untuk menaati Nabi; (4) Allah mewajibkan kepada hamba-Nya untuk melakukan ijtihad. Kewajiban melaksanakan 
kegiatan ijtihad sama kedudukannya dengan kewajiban menaati perintah lainnya yang telah ditetapkan oleh Allah bagi mereka yang memenuhi syarat.8Jadi, berdasarkan penjelasan di atas, hadis Nabi merupakan penjelas bagi ketentuan agama Islam melalui Alquran yang masih bersifat global.

Sebagian ulama lainnya menjelaskan bahwa yang dimaksud oleh ayat tersebut, S. al-Nahl:89, ialah semua ketentuan agama yang tercakup dalam ayat-ayat Alquran dan hadis Nabi. Hadis Nabi dicakup oleh ayat itu, karena salah satu fungsi Nabi menurut Alquran adalah menjelaskan Alquran.Di samping itu, Alquran telah mewajibkan orang-orang yang beriman untuk mengikuti petunjuk Nabi. ${ }^{9}$ Dengan demikian, sekali lagi, ayat tersebut sama sekali tidak menolak hadis Nabi, bahkan hadis Nabi merupakan bahagian tak terpisahkan dari ajaran Islam.

Selanjutnya, menurut kelompok ketiga, yakni kelompok yang mengingkari hadis ahad sebagai hujah

\footnotetext{
8Penjelasan al-Syafi'iy secara lebih lengkap, iihat al-Syafi'iy, al-Umm., h. 251-255; al-Syfifi'ry, al-Risalah (Jakarta: Dinamika Berkah Utania, t.th.), h. 15-16.

${ }^{9} \mathrm{AbÛ}$ Zahw, op. cit., h. 22; Muhammad íbn 'Ali ibn Ahmad al-Syaukâniy, Fath al-Qadîr, Juz III (Beirut Dår al-Fikr, 1973 M./1393 H), h. 187.
}

mengatakan bahwa dalam menerima suatu berita mestilah dengan suatu kehati-hatian (al-ihatah).hal itu akan didapat hanyalah melalui suatu pengetahuan benar yang bersumber dari Alquran, hadis yang disepakati (almujtama' 'alaih), dan kesepakatan seluruh manusia, seperti shalat zuhur itu empat rakaat. ${ }^{10}$ Argumen yang diajukan kelompok inipun di tentang oleh .Menurutnya, kelompok ini kurang paham tentang tingkatan-tingkatan yang ada dalam pengetahuan.Pengetahuan, lanjut alSyafi'iy, mempunyai dua tingkatan, yaitu pengetahuan yang membawa suatu keyakinan dan pengetahuan yang membawa zan.Secara tidak sadar, dalam kehidupan sehari-hari sering terjadi perbuatan ini.Seorang hakim meskipun telah dilengkapi berbagai alat-alat bukti, tetap juga tidak terlepas dari kesalahan.Oleh karena itu, apabila dalam hadis ahad ada yang mengandung kesalahan periwayat adalah wajar. ${ }^{11}$ Selain itu, al-Syafi'iy mengajukan beberapa dalil Alquran dan hadis Nabi penguat argumennya:

1. Alquran S. Nuh: 1 berbunyi:

10Al-Syfi'iy, al-Umm., h. 278.

${ }^{11}$ Ibid. 


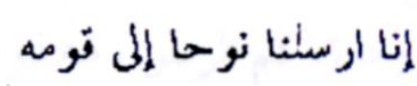

Artinya:".....Dan Kami utus Nuh kepada kaumnya"

Menurut ayat itu, Nabi Nuh ketika diutus Allah menyiar berbagai ajaran-Nya tidak bersama-sama dengan Nabi-Nabi yang lain, tetapi ia diutus secara sendiri (ahad).

2. Hadits Abdullah ibn Mas'ud

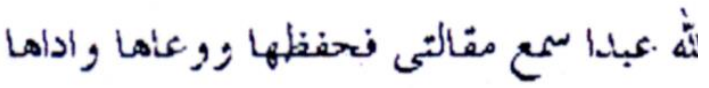

Artinya:

"Semoga keselamatan dan Allah kepada seorang hamba yang mendengar perkataanku, kemudian ia sadar dan menyampaikan sebagaimana ia terima berita itu"

Hadis di atas menunjukkan bahwa yang dimaksud orang yang menyampaikan adalah seorang.Artinya, sebagaimana dikemukakan al-Syafi'iy, penyampaian itu dibolehkan oleh Nabi bagi orang perseorang, baik dalam menyampaikan hal-hal yang bersifat halal maupun yang bersifat haram. ${ }^{12}$ Dengan demikian, tidak

${ }^{12}$ Al-Syafi'iy, Al-Risalah, op.cit., h. 392. mungkin hadis ahadditolak kehujahannya sedangkan Nabi sendiri membolehkannya.

Dalam Alquran banyak sekali ayat-ayat yang menjelaskan bahwa hadis merupakan sumber ajaran Islam di samping Alquran.Jumlah ayat-ayat tersebut dalam penelitian Muhammad Fuad 'Abd al-Baqiy lebih dari lima puluh ayat ${ }^{13}$. Diantaranya adalah:

1. Alquran S. al-Hasy: 7

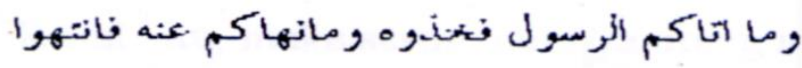

Artinya:"...Apa yang diberikan oleh Rasul kepadamu, maka hendaklah kamu menerimanya; dan apa yang dilarangnya, maka bagimu hendaklah kamu meninggalkannya (apa yang dilarangnya itu)"

Menurut ulama, ayat tersebut memberi petunjuk secara umum, yakni bahwa semua perintah dan larangan yang berasal dari Nabi wajib dipatuhi oleh orang-orarg yang beriman. ${ }^{14}$ Dengan demikıan, kewajiban

${ }^{13}$ Muhammad Fu'ad 'Abd aI-Baqiy.alMu'jam ul-Mufahras li Alfaz al-Qur'an al-karim (Bandung: Angkasa, t.th), h. 314-319, 429-430, dan 463-464.

14Lihat Abu Muhammad ibn Ahmad alAnsari, al-Jami' li Ahkam aI-Qur'an, Juz XVII 
patuh kepada Nabi menıpakan Artinya: "Barangsiapa yang mematuhi konşekuensi logis dari keimanan Rasul ıtu, maka sesungguhnya orang itu seseorang. telah mematuhi Allah".

2. Alquran, S. Ali Imran: 32,

Ayat tersebut mengandung petıuijuk bahwa kepatuhan kepada والرسول زان ثولوا فان الله لايكب الكا فرين Rasulullah merupakan salah satu tolak ukur kepatuhajı seseorang kepada Artinya:"Katakanlah: Taatilah Allah dan Rasul-Nya; apabila engkau berpaling, maka (ketahullah) sesungguhnya Allah tıdak menyukai oratıg-orang yangkafir".

Menurut penjelasan ulama, ayat tersebut memberi petunjuk bahwa ketaatan kepada Allah adalah dengan mematuhi petunjuk Alquran, sedang bentuk ketaatan kepada Nabı adalah dengan mengikuti sunnah atau hadis beliau. ${ }^{15}$

3. Alquran, S. an-Nisa': 80,

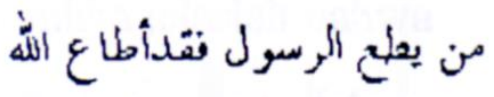

(Kairo: Dar al-Kitab 'Arabiy, 1967 M/1387 H), h. 17; Abu al-Qasim Jar Aflah Mahniud ibn Umar al-Zamakhsyariy, al-Kasyaf 'an Haqa'iq al-Tazil wa 'Uyun al-Aqawil.Juz IV (Mesir Mustafa alHalabiy al-Halabiy, t.th), h. 82.

15Rasyid Rida, Tajsîr al-Manår, Juz Ш (Beirut: Dâr al-Ma'anf, 1973 M./1388 H.), h285.

Allah ${ }^{16}$

4. Alquran, s. al-Ahzab: 21,

لقد كان لكم فيرسول الله أسوه حسنة لمن يرجوا الله واليوم الا خر وذكرالله كثيرا

Artinya: "

"Sungguh telah ada pada diri Rasulullah keteladanan yang baik bagunu, (yakni) bagi orang yang mengharap (akan rahmat) Allah, (meyakini akan kedatangan) hari kiamat, dan banyak menyebut (dan ingat akan) Allah".

Ayat di atas memberi petunjuk tentang tata cara meneladani Nabi Muhammad. Bagi mereka yang sempat bertemu dengan Rasulullah, maka cara itu dapat dilakukan secara langsung, sedang bagi mereka yang tidak sezaman dengan Rasulullah, maka cara meneladani adalah dengan mempelajari, memahami, dan mengikuti berbagai petunjuk yang

16 M. Syulıudi Ismail, Metodologi Penelitian Hadis Nabi (Cet. I; Jakarta: Bulan Bintang. 1992), h. 9. 
termuat dalam sunnah dan hadis beliau ${ }^{17}$.

Dengan melihat berbagai ungkapan ayat diatas, maka jelaslah bahwa hadis atau sunnah Nabi Muhammad merupakan sumber ajaran Islam, disamping Alquran. Orang yang menolak hadis sebagai salah satu sumber ajaran Islam berarti orang itu menolak petunjuk Alquran.

Dalam bidang hukum Islam, pernyataan Alquran sebagai sumber hukum Islam dan hadis sebagai sumber pula, bukanlah merupakan indikasi bahwa pada masing-masing sumber berdiri sendiri, sehingga mencerminkan ketiadaan hubungan antara keduanya. Namun sebaliknya, antara kedua sumber itu saling berhubungan dan merupakan satu kesatuan yang berasal dari Tuhan. ${ }^{18}$ Alquran menggambarkan hubungan tadi dengan mengatakan bahwa setiap apa saja yang keluar dan Nabi, baik Alquran maupun hadis, tidak lain merupakan wahyu yang tidak tercampur di dalamnya keinginankeinginan pribadi, Berikut dikutip

\footnotetext{
17 ibid

18 Muhammad Khudariy Bik, Usäl alFiqh (Mesir al-Maktabat al-Tijariyat alKubra,1992 M.), h. 242.
}

firman Allah tersebut,

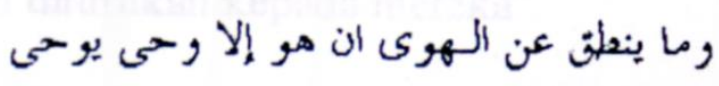

Peristilahan

untuk menggambarkan hubungan Alquran dan hadis lazim disebut dengan rutbah atau manzilah; Alquran diletakkan sebagai urutan pertama dan hadis diurutkan kedua. Dalam hal ini, alSyatibiy mengemukakan tiga alasan lebih tingginya tingkatan Alquran daripada hadis, yakni (1) Alquran diterima dengan jalan qat'iy, sedang hadis kebanyakan diterima melalui zarnniy, (2) hadis berstatus bayan bagi alquran; (3) adanya pernyataan hadis tentang urutan rutbah itu sendiri. ${ }^{19}$

Fungsi hadis sendiri bagi Alquran sacara umum dapat dikatakan sebagai penjelas (bayan) bagi Alquran.Diketahui, Alquran yang diturunkan selama 23 tahun, tidaklah secara keseluruhan menerangkan hukum berkenaan dengan fi'il mukallaf (perbuatan orang mukallaf). Memang adakalanya Alquran menerangkan hukum tersebut secara rinci, tetapi banyak pula yang masih global, bahkan terkadang tidak dijumpai sama sekali suatu keteranganpun dalam Alquran. Keadaan tersebut, tentu saja

${ }^{19}$ Abu Ishaq al-Syatibiy, al-Muwäfaqät, Juz IV (t.t,, : tp., t.th.), h. 7-8. 
membingungkan, maka untuk hukum, sering juga disebut dengan terlaksananya perintah syara' secara sempurna, karena ayat Alquran masih bersifat global atau ketiadaan hukum, Allah memberikan otontas kepada Nabi untuk memberikan penjelasan (bayan) terhadap hal-hal tadi. Wujud pemberian wewenang tertuang dalam firman Allah S. al-Nahl: 44,

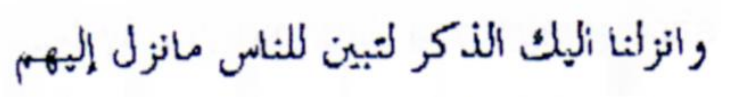

bayän nasakh.20

Umumnya para ulama sepakat pada sebagian besar fungsi hadis terhadap Alquran yang disebutkan. Perbedaan terjadi dalam hal fungsi hadis dalam menetapkan hukum yang tıdak desebutkan oleh Alquran, misalıya keharaman mengawıni wamta yang disebabkan sesusuan yang hanya did;ıpati ketentuan hukumnya dari hadis. Untuk fungsi ini, sebagaimana Artinya:

"... Dan kami tınınkan kepadamu Alquran, agar kamu menerangkan kepada umat manusia apa yang telah ditunıkan kepada mereka".

Ayat di atas memberi petunjuk lentang otoritas Nabi dan fungsi hadıs bagi Alquran, yaitu (1) bayän ta'kid, yaknı sebagaı penjelasan untuk mengokohkan apa yang terkandung dalam Alquran; (2) bayän tafsir, yakni sebagal penjelasan atau penerangan terhadap ayat-ayat yang mujmal (global) dan musytarak, (3) bayän takhsis, yakni menjelaskan tentang kekhususan suatu ayat yang umum; (4) bayän taqyid, yakni menjelaskan dan memberi batasan terhadap ayat Alquran yang bersit'at mutlak; (5) bayän tabäil, yakni mengganti suatu disebutkan al-Siba'iy, bukanlah tentang wujud hukum yung telah ditetapkan oleh hadis itu, tetapi berkisar pada masalah apakah hukum hadis itu berada di luar hukum-hukum Alquran secara umum. ${ }^{21}$

Menanggapi permasalahan ini, alSyäfi'iy nampak beıpegang pada pendapat bahwa ketentuan-ketentuan yang ada dalam hadis berada dalam hukum-hukum Alquran; Dengan katalam, hadis Nabı dapat saja menambah hukum yang ada dalam Alquran.Ia mengatakan bahwa wujud

20 Lihat penjelasan yaing saling me!engkapi Abü Zahrah, Usül al-Fiqh (t.t.: Där al-Fikr al-'arabiy, t.th.), h. 112; Ahmad Ibrahim Bik, 'llm Usül al-Fiqh (Kairo: Där al-Ansar, t.th ), h. 21; Mulıammad 'Ajaj Khatib, Usül ai-Hadis (Beirut Dar al-Fikr, 1989 M./1409 H.), h. 46-51.

21 Mustafa al-Siba'iy, al-Sunnah wa Makanatuhä fi Tasyrl' ai-Islämiy (t.t.: al-dar alQaumiyyah, t.th.), h. 346. 
perintah yang ada, baik dan alquran maupun hadis, adalah berpangkal dari sumber yang sama, meskipun melalui jalur yang berbeda. Berikut dikutip pernyataan al-Syäfi'iy tersebut: 22

لحمع القبول لمافى كتاب الله ، ولمنة رسول الله القبون لكل واحد منهما عن الله

Pernyataan al-Syäfi'iy di atas, menggambarkan persamaan kekuatan hukum yang dimılikı Alquran dan hadis. Hal itu teljadi, menurut al-Syäfi'iy, bermula dari adanya ketetapan Alquran sendin vang menyuruh manusia menaati $\mathrm{Nabi}^{23}$

\section{Pembagian Hadis}

Kalangan ulama ada yang membedakan pengertian hadis dan sunnah; dan ada pula yang menyamakannya. Sufyän al-Sauriy (w. 778 M./161 H.) dikenal sebagaı Imäm fi al-sunnah, al-Auza'iy (w. 774 m./157 H.) dikenal sebaliknya, sedang Malık jbn Anas dikenal sebagai Imam fi alhadis wa al-sunnah.Oleh karena itu, di antara ulama ada yang mengalalcan, pengertian hadıs lebıh umum daripada al-sunnah, dan ada ulama yang berpendapal sebaliknya. Selain itu, adajuga nlamayang berpendapat, hadis

${ }^{22}$ A1-Syäfi'iy, al-Risälah., h. 22. 23 ibid berisi petunjuk Nabi urituk tujuan praktis, sedaing al-sunnah merupakaaı hukum tirıgkah laku, baik teıjadı sekali saja maupun berulang kali, baik dılakukan oleh Nabi, sahabat nabi, ${ }^{24}$ tabi'in $^{25}$, maupun ulama lain pada umumnya. $^{26}$ Dalam uraian penılıs, istilah hadis dan sımnah disamakan pengertıannya dengan istilah hadıs sebagainıana yang dinyatakan oleh ulama hadis pada umumnya, yakni

24"Menurut istilah ilmu hadis yang disepekati oleh ulama hadis, sahabat adalah orang Islam yang pernah bergaul atau melihat Nabi dan meninggal dalam keadaan beragama Islam. Lihat $\mathrm{Abu}$ 'Amr 'Usman ibn 'Abd alRahman ibn al-Shalah, 'Ulum al-Hadis (Madinah; al-Maktabat al-'Ilmiyyah, 1972), h. 263-264; Abual-Fida' Isma'il ibn al Kasir, Ikhtisar 'Ulum al-Hadis, disyarah oleh Ahmad Muhammad Syakir dengan judul, al-Ba'is alHasis fi Ikhtisar 'Ulum al-Hadis (Beirut Dar alFikr, t.th), h. 94-95.

25 Kata tabi'ln merupakan jarnak daii al-täbi'iy atau al-tähi' yang berart: yang melıgikutinya. Menurut istilah lmu hadis, maka ia berarti orang Islam yang pernah beitemu dengan seorang sahabat Nabi atau lebih dan meninggal dalam keadaan beragama Islam. Lihat Ibın al-Salah, op. cit., h. 271-272; Mahmud al-Tahan, Taysir Mustalah aL-Hadis (Beirut: Där al-Qur'an al-Karim, 1975 M/1399 H.), h. 201.

26 keterangan selanjutnya, lihat alSyätibiy, op. cit., h. 3-7; Muhanımad 'Abd aiAzim al-Zarqarniy, Syarh al-Zarqaniy 'ala Muwata al-lmam Malık (Beirut: Där al-Fıkr, 1936 M./1355 H.), h. 3; Fazlurahman, Islam (Chicago: University of Chicago Press, 1979 M), h 53-58' Syed Mahmudunnasir, Islam in Concept and History (New deihi: Nusrat Ali Nasri for Kitflb Bhavan, 1981 m.), h 108-115. 
segala sabda, perbuatan, iaqrir, dan sifat Rasulullah saw. ${ }^{27}$

Kata hadis itu sendiri berasal dan bahasa Arab: al-hadis .jamak dari kata ini, al-ahädis, al-hidsän, atanl alhudsan.Kata hadis ini juga telah menjadı salah satu kosakata bahasa Indonesia. Hanya saja pengertian yang diberikannya kurang lengkap, khususnya yəng berkenaan dengan taqrir $^{28}$.

Adapun dari segı bahasa, kata ini memiliki banyak arti, (1) al-jadid (yang baru), lawan dan al-qadim (yang lanıa); dan (2) al-khabar (kabar atau berita). ${ }^{29}$ Secara istilah, hadis diberikan pengeitian yang berbeda-beda.Dalam pengertıan ulama ıısül al-fiqh dikemukakan bahwa yang dimaksud hadıs adalah aktivitas langsung alaupun tidak langsung darı Nabi.Sedangkan

27 Subhi al-Salih,' Ulüm al-Hadis wa Mustalahuhu (Beirut Där 'Ilm li al-Malayill, 1977 M.), h. 3; Muhammad al-Sabbag, al-Hadis al-Nabawiy (Riyad: Maktabat al-Islamiy, 1972 M/1392 H.), h. 14-16.

28 W.J.S. Poerwadarminta, Kamus Umun Balıasa Indonesia (Jakaıta: Balai Pıstaka, 1985 M), h. 338; Hassan Shadily, Ensiklopedi Indonesia, Jilid II (Jakarta: Ichtiar Baru-Van Hoeve), h. 1198.

29 Muhammad ibn Mukarram ibn Manzur, Lisän al-'Arab, Juz n (Mesir Där alMisriyyah, t.th. ), h. 436-439; Ahmad ibn Ahınad al-Fayyuniiy, al-Misbah al-Munir fiy Garib alSyarh al-Kabir li al-Rafi', Juz I (Beirut Där alKutub al-'Ilmiyyall, 1978 M/1398 H.), h. 150151; Maj al-Din Abu Sa'adat al-Mubarak ibn al'Asir, al-Nihayah fiy Garib al-Hadis, Juz J (t.t.: 'Isa d-Bäbiy al-Halabiy, t.th.), h. 350-351. pengertian hadis menurut istilah ulama hadis, masih dımungkinkan adanya sesuatu yang bukan dari aktıvitas Nabı, misalnya tentang warna rambut, memanjangkan jenggot. ${ }^{30}$ Selain itu, menurut Ibn al-Subkiy (w. 1370 M./771 $\mathrm{H}$ ), pengertian hadıs, yang dalam hal ini disebut juga dengan istilah alsunnah, adalah segala sabda dan perbuatan Nabi Muhammad saw.

Dalam pengertian Ibn alSubkiy, ia tidak memasukkan unsur taqrir Nabı sebagai bagian dari rumusan hadis. Menurutnya, karena taqrir itu telah masuk kedalam bentuk lain dan perbuatan (af'äl) Nabi, maka hal itu tidak perlu dikemukakan lagi. Apabila dıkemukakan juga, makarumusan definisi akan menjadı tıdak terhindar dan sesuatu yang tidak didefinisikan (qair mani ').31

Agak berbeda dengan pandangan yang disebutkan, Ibıl Hazm, seorang pengikut aliran Zahiriyyah tidak menyetujui apabila seluruh perbuatan

${ }^{30}$ untuk memperjelas pengertian istilah menurut kedua golongan itu, lihat al-Khatib, op.cit., h. 17-28; 'Abbas Mutawalli Hamadah, alSunnah al-Nabawiyah wa Makanatuha fi alTasyri' (tt..: al-Dar al-Qaumiyyah, t.th), h. 13-23.

31Lihat selanjutny al-Banäniy. Häsylyah 'ala Syarh Muhammad ibn Ahmad al-Mahalliy 'ala Matn Jam' al-Jawami' li al-Imäm Täj al-Din 'Abd al-Wahab ibn al-Subkiy, Juz II (t.t.: Där alIhya' al-Kutub al-'Arabiyyah, t.th.), h. 94-95. 
Nabi masuk ke dalam kategorı hadis. Baginya, perbuatan (af'äl) Nabi baru dapat dikategonkan sebagai hadis, jika perbuatan itu didıkung oleh perkataan Nabi yang menyuruh mclakıkannya, misalnya perbuatan shalat yang didukung oleh ucapan Nabi yang menyuruh melakukan. ${ }^{32}$

Dalam sejarah perkembarıgan hukum Islam, pengertian hadis dalam hal im disebut sebagaı sunnah, menurut Schacht dengan mengutip pendapat dan Goldziher, bahwa yang simnah pada masa sebelum al-Syäfi'iy tidaklah selalu berarti perbuatan-perbuatan Nabi, tetapi lebıh balıyak berarti bentuk tradisı terdahulu. Al-Syäfi'iy, masih menurut Schacht, adalah orang pertama yang memprakarsal pembatasan arti sumıalı sebagai perbuatan-perbuatan Nabi Muhammad saw.art sich. Berıkut dikutıp tuhsan Schacht tersebut:

"It is one the main result of this part of this book, that Syafi'iy was the first lawyer to deftne sunnah as the model behaviour of the prophet, in contrast with his predecessors for whom it was not necessarily connected with the prophet, but represented the traditional,

32 -'Muhanmıad Abü Zahralı, Tärikh alMazähib al-Islämiyyah, Juz II (t.t.: Dar al-Fikr al'Arabiy, t.th), h. 791. albeit ideal, usage of the commimity, forming their "living tradition" on an equal footing with customary of generally agreed practice" 33

Selain itu, pada masa pra alSyäfi'iy, muncul perbedaan arti antara sunnah dan hadis. Disebut dengan sunnah, maka berarti keseluruhan tradisi yalı telah dikenal balk dan praktek-praktek yang sudah umum dan mapan dari kaum Muslimin. Sedangkan hadis, diartıkan dengan penuturan hukum-hukum yang sudah pasti dinyatakan oleh Rasulullah. ${ }^{34}$ Setelah kedatangan al-Syäfi'ıy, ia menentang adanya perbedaan pengertian antara keduanya. Ia mendesak untuk mengartikan sunnah hanya sebagai tradisi yang dijamin asli berasal dari Rasulullah. ${ }^{35}$ Jadi, dalam batasini al-

33 Joseph Schacht, The Origins ofMuhammadan Jurispmdence (Cet I; London: Oxford University Press, 1975 M ), h. 2.

${ }^{34}$ Ahmad Hasan, The Early Develepment of islamic Jurisprudence.Diterjemahkan oleh Agah Garnadidengall judul Pintu ljtihad Sebelum Tertutup (Cet I; Balldung: Pust\&ka, 1970 M.), h. 78.

35Dalam keterailgan catatan kaki tulisan Ahınad Hasan disebutkan bahwa alSyäfi'iy bukanlah ahli hukum yang pertama sekali mengidenfikkan sumnah dengan hadis; di masa lalu, telah terdapat sejumlah orang yang memıliki gagasan deınikian, misalnya Salih ibn Kaysan (w. 140 H.). Lebih lanjut, lihat Ibid., h. 79 dan 226 
Syafi'iy mengidentikkan arti sunnah dengan hadis.

Al-Syäfi'iy membagı hadıs yang datang dari Nabi Muhammad saw. kepada dua, yaitu (1) khabar al- ammah dan (2) khabar al-khäsah³ Untuk beniuk pertama ulama lainnya menyebutnya dengan istilah mutawatir ${ }^{37 a l-S y a ̈ f i ' i y ~ t e r k a d a n g ~}$ menyebutkan bentuk ini dengan alkhabar al-mujtama' 'alaih.

Apabıla dikatakan suatu khabar Itu 'ämmah (umum), maka menurut alSyäfi'iy itu berartı yang diterima oleh banyak orang, kemudianmereka mengamalkannya. Dalam hal mi, semua orang, baik orang berilmu maupun yang awwam sama pengetahuannya tentang berita itu. Ia memberikan

36 "Muhammad ibn Idris al-Syäfi'iy, Ikhtilaf al-Hadis, ditahkik oleh Muhammad Ahmad 'Abd al-aziz (Cet, I; Beirut: Där al-Kutb al-'Dmiyyah, 1986 M/1406 H ), h. 13.

${ }^{37}$ Secara literal mutawatir berarti tatabu',yakni berurut. Dalam ilmu" hadis, mutawatir berarti berita yang diriwayatkan oleh orang banyak pada setup tingkat periwayat, mulai dai tingkat sahabat sampai dengan mukharrij hadis, yang menurutt ukuran rasio dan kebiasaan, mustahil para periwayat dengan jumlah yang banyak itu bersepakat terlebih dahulu untuk berdusta. Selanjutnya lihat Subhi al-Salih, op. cit., h. 146-147; alTahan, op. cit., h. 18-22; al-Khatib, op. cit, h. 302-303; al-Sabbag, op. cit., h. 167-168; Ahmad ibn 'Ali ibn Hajar al-'Asqalaniy, nahatun Nazar Syarh Nukhbat al-fikr (Semarang: Maktabah alMuanawwar, t.th.), h. 9. contoh, seperti jumlah bilangan shalat, dan kewajiban puasa bulan Ramadhan.

Ulama berbeda pendapat tentang jumlah periwayat yang mesti dipenuhi pada setiap tingkatan sanad-nya untuk disebutkan suatu hadis berstatus mutawatir. Sebagian ulama mengatakan lima orang dengan menjadikan kepada lima orang ulil alAzmi dari Nabi-nabi. Sebagian lainnya mangatakan tujuh orang sebagai qiyäs dari tujuh orang, ashdb al-kahfi Ada juga yang mangatakan sepuluh orang, dua puluh orang, empat puluh orangseperti jumlah yang wajib dipenuhi dalam shalat jum'at, dan lain sebagainya yang kesemuanya merujuk kepada jumlah tertentu dari penwayat. Hal tersebut dianggap oleh Wahbah Zuhailiy sebagai pendapat yang lemah dan tidak bersandarkan kepada rasio serta dalil tertulis yang kuat.Menurutnya, dalam menentukan status mutawatir-nya, suatu hadis tidaklah didasari pada jumlah tertentu pada periwayat, tetapi pada dasar pengetahuan dan keyakinan yang dirangkum dari pendapat-pendapat orang-orang terdahulu. $^{38}$ Dengan demikian, dapat saja suatu hadis yang

38 Wahbah al-Zuhailiy, Usüi ai-Fiqh alIslämiy, Juz I (Cet I: Demsyiq: Dar al-Fikr, 1986 M./1406 t.t), h. 453. 
semula hanya diriwayatkan oleh beberapa orang saja, tetapi setelah diteliti ia membawa keyakinan untuk ditingkatkan statusnya menjadi mutawatir.

Untuk hadis mutawatir, ulama menganggap tidak perlu dilakukan penelitian lebih lanjut tentang kualitasnya; hadis mutawatir pasti berkualitas sahih.Oleh karena itu, mutawatir telah membawa keyakinan yang pasti bahwa hadis yang bersangkutan berasal dari Nabi. ${ }^{39}$

Pernyataan ulama tersebut tidaklah berarti bahwa terhadap hadis yang berstatus mutawatir tidak dapat dilakukan penelitian lagi.Penelitian terhadap hadis mutawatir tetap saja mesti dilakukan, hanya saja yang menjadi tujuan penelitian bukanlah untuk mengetahui bagaimana kualitas sanad dan matan hadis yang bersangkutan.Penelitian yang dimaksud adalah untuk membuktikan apakah benar hadis tersebut berstatus mutawatir.Apabila penelitian membuktikan hadis itu memang berstatus mutawatir, maka tidak perlu diadakan penelitian terhadap sanad dan matan hadis yang bersangkutan.

29.
Selanjutnya mengenai khabar alkadsah, al-Syäfi'iy mendefinisi-kannya sebagai hadis yang diriwayatkan oleh seorang penwayat dari seorang periwayat sampai ke Nabi Muhammad saw. ${ }^{40}$ Pengertian seperti ini umumnya diterima oleh kebanyakan ulama. Bahkan, mereka bersepakat bahwa yang disebut hadis $\operatorname{ahad}^{41}$ adalah hadis yang tidak mencapai tingkatan mutawâtir ${ }^{42}$

Menurut sebagian ulama, status Wurûd (kedatangannya) hadis ahâd adalah zanniy ${ }^{43}$ Mereka beralasan

${ }^{40}$ Al-Syäfi'iy, al-Risälah., h. 120. Ulama aliran Hanafiyyah (baca; pengikut Abu Hanifah) menceraikan dari pengertian hadis ahad ini satu bentuk lain, mereka menyebutnya dengan hadis masyhur, yaitu hadis yang pada tingkat sahabat diriwayatkan secara ahad, tetapi pada tingkat berikutnya diriwayatkan oleh banyak orang yang tidak mungkin mereka bersepakat berdusta. Penjelasan selanjuüıya, lihat alZuhailiy, loc. cit.

${ }^{41}$ Ahäd adalah kata bahasa Arab yang muhtamil jama' dari wahıd, seperti pada asyhad jama' dari syahid, sebagaimana jamak ahäd, seperti sabab jamaknya asbab.Kata wahid mempunyai arti satu.Dengan demikian, kata ahad /berarti satuan, yaitu angka bilangan dari satu sampai sembilan.Selain itu, kata ahad dapat juga berarti satuan dari satu suku dari sesuatu. Penjelasan saling melengkapi, lihat alTahan, op. cit., h. 21; M. Hasbi Ash Shiddieqy, Pokok-Pokok Ilmu Dirayah Hadist, Jilid I (Jakarta: Bulan Bintang, 1987 M.), h 66; M. Syuhudi Ismail, Pengantar Ilmu Hadis (Bandung: Angkasa, 1991 M.), h. 141.

42 Al-Tahan, loc.cit; Abû Zahrah, Usûl,., h. 108; al-Khatib, op. cit., h. 302; alKhallaf,op.cit., h. 42.

43Kafa-kata zanniy bersama-sama dengan qat 'iy adalah istilah yang sering digunakan oleh para ulama dan pemikir Islam 
bahwa hadis ahad diriwayatkan oleh periwayat yang jumlahnya tidak menimbulkan keyakinan yang pasti kebenarannya.Dalam padaitn, mereka juga berpendapat bahwa status zanniy tidak menghilangkan kewajiban untuk mengamalkannya. ${ }^{44}$

Tentang kewajiban beramal dengan hadis ahad, ulama memang berbeda pendapat.Perbedaan tersebut didasari pada status hadis ahâd itu sendiri, yakni apakah hadis tersebut membawa suatu keyakinan (al-yaqin $\left.{ }^{45}\right)$ atau tidak. Ahmad ibn Hanbal, sebagian pemuka hadis, Daûd al-Zâhiriy, dan pengikutnya Ibn Hazm berpendapat bahwa hadis ahâd apabila terbukti dalam kaitannya dengan pembahasan kedudukan Alquran dan hadis Nabi dilihat dari wurud-nya (kedatangan) atausubui-nya (penetapan).Adanya pembagian ini adalah dalam rangka mengetahui "kawasan" ajaran Islam yang dapat dilakukan ijtihåd dan yang tidak dapat.Penjelasan lebih lanjut, lihat Syuhudi.Hadis., h. 92.

${ }^{44} \mathrm{Abu}$ Zakariya Yaliya ibn Syaraf alNawawiy, Sahih Muslim bi Syarh al-Nawaâwiy, Juz I (Mesir: al-Matba'ah al-Misriyyah, 1924 M.), h. 20; Salim 'Ali al-Bahnasawiy, al-Sunnah al-Maftara 'alaiha (t.t.: Dâr al-BuhÛs al'Ilmiyyah, 1979 M.), h. 100-109.

${ }^{45}$ Dalam ilmu Usûl al-fiqh ada empat kaidah mengenai teori pengetahuan : (1) yaqîn, atau keyakinan yang membawa suatu hukum; (2) zan, atau waham yang tidak dapat membawa hukum; (3) al-Wahm, atau waham yang tidak dapat membawa hukum, disebabkan adanya pertimbangan sama antara dua kasus tertentu; dan (4) al-Syak, keraguan yang tidak membawa suatu hukum. Selanjutnya lihat 'Abd al-Hamid Hakim.al-Bayån (Jakarta: Sa'adiyah Putra, t.th.), h. 5. benar dan Nabi, maka dia membawa keyakinan. Hal itu berbeda dengan yang dipegang oleh pengikut-pengikut Hanafî, Syâfi'iy, Mâlikiy, dan lainnya, bahwa menurut mereka hadis ahad hanya membawa suatu yang zanniy, tetapi itu cukup sebagai dasar kewajiban beramal dengan hadis ahad. Karena,masih menurut golongan yang terakhir disebutkan, zati yang ada pada hadis ahâd adalah dugaan yang benar (al-zan al-råjih). ${ }^{46}$ Jadi, meskipun ulama berbeda dalam menentukan kadar pengetahuan ('ilm) yang dimiliki hadis ahâd, tetapi mereka sepakat tentang kewajiban beramal dengan hadis ahâd.

Mengenai hadis mursal ${ }^{47}$ Syâfi'iy membaginya kepada dua bagian,

${ }^{46}$ Ali ibn Ahmad ibn Hazm, ai-Ihkâm fi l.hãl aí-Ahkâm, Juz I (Cet I; Kairo: al-Khanijiy, 1345 H.), h. 97, daii 108-122; Syaf al-Din 'Aliy ibn Muhammad al-Amidiy, ai-Ihkâm fi Usûl alAhkâm, Juz II (Mesir Dår al-Ma'arif, 1914 M.1333 H.), h. 49-60; Abu Hamid al-Gazaliy, alMustasfa min 'llm al-UsũI, Juz 1 (Cet. I; Mesir tp., 1356 H.), h. 93-99.

47Ulama dari kalangan pengikut $\mathrm{Abu}$ Hamtzh dan Malik menerima hadis mursal sebagai hujjah, dengan syarat orang-orang yang meriwayatkan hadis itu seluruhnya adalah orang kepercayaan.Alasan mereka. (1) bahwa periwayat yang adil niscaya tidak akan menggugurkan periwayat yang berada antara dia dan Nabi, sekiranya periwayat yang digugurkan im bukanlah orang adil pula; dan (2) adanya hadis Nabi yang memuji kepada generasi sahabat dan îabi'in. Selanjutnya, lihat al-Tahan,op.cit., h. 72; al-Ikhtilaf fi al-Qawa'id al-Usuliyah fi Ikhtilaf al-Fuqaha' (Cet. H; Beirut: Muassasat al-Risalah, 1981 M/1401 H ), h. 401402. 
mursal iabi 'în besar (kibår al-tâbi'in) dan tabi 'înkecil (siqar al-abi'in).48 Untuk yang disebutkan terakhir kali, alSyâfi'iy menolaknya dijadikan hujjah.Ia memberikan tiga alasan, (1) hadis mursal yang mereka sebutkan sampai ke Nabi terlalu jauh melompat; (2) hadis mursal seperti ini tidak jelas sumbernya; dan (3) seringnya terjadi penyimpangan yang mengakibatkan salah dalam mengartikannya. ${ }^{49}$

Adapun mursal tabi'in besar, ia membolehkannya dengan syarat, (1) Tabi'in yang menggugurkan adalah tabi'în besar yang memang berjumpa dengan sebagian besar sahabat, misalnya, Sa'îd ibn Musayyab dan alHasan al-Basriy; (2) Matan hadis tersebut diriwayatkan oleh sanad lain yang muttasil atau hadis mursal lain yang ber-sanad lain pula, atau disaksikan kebenaran hadismursalitu oleh fatwa sahabat; (3) periwayat hadis mursal itu adalah orang yang

\footnotetext{
48 Alimad Nakhrawiy ' Abd al-Salåm.alImâm al-Syâfi 'iy fi Mazhabaih al-Qadim $w$ a alJadĩd(t.t.: tp., 1988 M.), h. 362; Ahmad Yusuf, op. cit., h. 78-79. Sesunggunnya istilahyang dipakai al Syâfi'iy untuk menunjukkan tabi'în kecil bukanlah sigar ai-tabi'ĩn.Istilah tersebut merupakan kesimpulan dari pernyataan alSyâfi'iy yang ditulisnya dengan man ba'da kibâr al-tabi'îfi, lihat al-Syâfi'iy, al-Risâlah., h. 200.

49lbid, Nakhrâwiy, op. cit., h. 365; Ahmad Yusuf, loc. cit.
}

adil.50Uraian syarat-syarat yang diajukan al-Syåfi'iy untuk menjadikan hadis mursal sebagai hujah dapat disebut ketat.Hal itu disebabkan, keterputusan sanad yang dimiliki oleh hadis mursal.Sesungguhnya al-Syâfi'iy, sebagaimana ditulis oleh al-Ghazaliy, sangat menolak hadis mursal. ${ }^{51}$

\section{Daftar Pustaka}

'Abd al-Hamid Hakim.al-Bayån, Jakarta: Sa'adiyah Putra, t.th.

Abu al-Qasim Jar Aflah Mahniud ibn Umar al-Zamakhsyariy, alKasyaf 'an Haqa'iq al-Tazil wa 'Uyun al-Aqawil. Juz IV (Mesir Mustafa al-Halabiy al-Halabiy, t.th.

Abu 'Amr 'Usman ibn 'Abd al-Rahman ibn al-Shalah. 1972. 'Ulum alHadis Madinah; al-Maktabat al'Ilmiyyah.

Abu Hamid al-Gazaliy. 1356 H. alMustasfa min 'Ilm al-UsũI. Juz 1, Mesir.

Abu Muhammad ibn Ahmad al-Ansari. 1967 M/1387 H. al-Jami' li Ahkam aI-Qur'an. Juz XVII. Kairo: Dar al-Kitab 'Arabiy.

Abu Zahrah. al-Syafi 'iy. Kairo: Dar alFikr al-'Arabiy. t.th.

Abu Zakariya Yaliya ibn Syaraf alNawawiy. 1924. Sahih Muslim bi Syarh al-Nawaâwiy. Juz I (Mesir: al-Matba'ah al-Misriyyah.

50Al-Syåfi'iy, al-Risâlahh. 200.

51A1-Ghazalíy, op. cit.y 129. 
Agah Garnadidengall. 1970. Pintu ljtihad Sebelum Tertutup. Balldung: Pustaka.

Ahmad ibn Ahınad al-Fayyuniiy. 1978 M/1398. al-Misbah al-Munir fiy Garib al-Syarh al-Kabir li al-Rafi'. Juz I. Beirut Där al-Kutub al'Ilmiyyalı.

Ahmad ibn 'Ali ibn Hajar al-'Asqalaniy. nahatun Nazar Syarh Nukhbat al-fikr. Semarang: Maktabah alMuanawwar. t.th.

Ahmad Yusuf. al-Syafi'iy Wadi' 'llm alUsuI. Kairo: Dar al-Saqafah, t.th.

al-Ikhtilaf. 1981 M/1401 H. fi alQawa'id al-Usuliyah fi Ikhtilaf alFuqaha. Beirut: Muassasat alRisalah.

Ali ibn Ahmad ibn Hazm. 1345 H. aiIhkâm fi l.hãl aí-Ahkâm. Juz I. Kairo: al-Khanijiy.

Alimad Nakhrawiy 'Abd al-Salåm. 1988. al-Imâm al-Syâfi 'iy fi Mazhabaih al-Qadim w a al-Jadĩd.

Ali Sâyis. 1970. Nasy'at al-Fiqh alijtihådiy wa Atwaruhu.. Silsilat aJ-Buhus al-lslâmiy.

Al-Syafi'iy al-Risalah (Jakarta: Dinamika Berkah Utania, t.th.

Fazlurahman. 1979. Islam. Chicago: University of Chicago Press.

Hasbi Ash Shiddieqy. 1987. PokokPokok Ilmu Dirayah Hadis. Jilid I. Jakarta: Bulan Bintang.

Hassan Shadily, Ensiklopedi Indonesıa, Jilid II, Jakarta: Ichtiar Baru-Van Hoeve.
Joseph Schacht, 1975. The Origins ofMuhammadan Jurispmdence, London: Oxford University Press.

Muhanımad 'Abd ai-Azim al-Zarqarniy. 1936 M./1355. Syarh alZarqaniy 'ala Muwata al-lmam Malık, Beirut: Där al-Fıkr.

Muhammad Abu Zahw, al-Hadis wa almuhadisun. Mesir Matba'at Misr.

Muhanmad Abü Zahralı, Tärikh alMazähib al-Islämiyyah, Juz II. t.t.: Dar al-Fikr al-'Arabiy, t.th.

Mulıammad 'Ajaj Khatib. 1992 M. Usül ai-Hadis. Beirut Dar al-Fikr, 1989 M./1409 H.

Muhammad al-Sabbag. 1972 M/1392 H. al-Hadis al-Nabawiy. Riyad: Maktabat al-Islamiy.

Muhammad ibn Idris al-Syãfi'iy. alUmm. Juz VII. Dâr al-Sya'b, t th.

Muhammad ibn Idris al-Syäfi'iy. 1986 M/1406 H. Ikhtilaf al-Hadis. ditahkik oleh Muhammad Ahmad 'Abd al-aziz, Beirut: Där al-Kutb al-'Dmiyyah.

Muhammad íbn 'Ali ibn Ahmad alSyaukâniy. 1973. Fath al-Qadîr. Juz III. Beirut Dår al-Fikr.

Muhammad Fu'ad 'Abd aI-Baqiy, alMu'jam ul-Mufahras li Alfaz alQur'an al-karim, Bandung: Angkasa, t.th.

M Syuhudi Ismail. 1995. Hadits Nabi Menurut Pembela Pengingkar dan Pemalsunya. Jakarta: Gema Insani Press. 
M. Syulıudi Ismail. 1992. Metodologi Penelitian Hadis Nabi, Jakarta: Bulan Bintang.

Muhammad Khudariy Bik, Usäl al-Fiqh, Mesir al-Maktabat al-Tijariyat al-Kubra.

Mustafa al-Siba'iy. al-Sunnah wa Makanatuhä fi Tasyrl' ai-Islämiy. al-dar al-Qaumiyyah, t.th.

Mahmud al-Tahan. 1975 M/1399 H. Taysir Mustalah aL-Hadis. Beirut: Där al-Qur'an al-Karim

Rasyid Rida. 1973 M./1388 H. Tajsîr alManår. Juz Ш. Beirut: Dâr alMa'anf.

Salim 'Ali al-Bahnasawiy. 1979. alSunnah al-Maftara 'alaiha. Dâr al-BuhÛs al-'Ilmiyyah.

Subhi al-Salih'. 1981. Ulüm al-Hadis wa Mustalahuhu, Beirut Där 'Ilm li al-Malayiı, 1977.

Syaf al-Din 'Aliy ibn Muhammad alAmidiy. 1914 M.-1333 H. ai-Ihkâm fi Usûl al-Ahkâm, Juz II, Mesir Dår al-Ma'arif.

Syed Mahmudunnasir, Islam in Concept and History, New deihi: Nusrat Ali Nasri for Kitflb Bhavan.

Syuhudi Ismail. 1991 M. Pengantar Ilmu Hadis. Bandung: Angkasa.

Wahbah al-Zuhailiy. 1986 M./1406. Usüi ai-Fiqh al-lslämiy, Juz I, Demsyiq: Dar al-Fikr.

W.J.S. Poerwadarmiınta. 1985. Kamus Umum Balıasa Indonesia. Jakaita: Balai Plıstaka. 